Columbia Law School

Scholarship Archive

2009

\title{
Legal Frameworks and Institutional Contexts for Public Consultation Regarding Administrative Action: The United States
}

Peter L. Strauss

Columbia Law School, strauss@law.columbia.edu

Follow this and additional works at: https://scholarship.law.columbia.edu/faculty_scholarship

Part of the President/Executive Department Commons, and the Science and Technology Law Commons

\section{Recommended Citation}

Peter L. Strauss, Legal Frameworks and Institutional Contexts for Public Consultation Regarding Administrative Action: The United States, Columbia Public LaW ReseARCH PAPER No. 09-221 (2009).

Available at: https://scholarship.law.columbia.edu/faculty_scholarship/1596

This Working Paper is brought to you for free and open access by the Faculty Publications at Scholarship Archive. It has been accepted for inclusion in Faculty Scholarship by an authorized administrator of Scholarship Archive. For more information, please contact scholarshiparchive@law.columbia.edu. 


\section{Columbia Law School}

Public Law \& Legal Theory Working Paper Group

Paper Number 09-221

\section{LEGAL FRAMEWORKS AND INSTITUTIONAL CONTEXTS FOR PUBLIC CONSULTATION REGARDING ADMINISTRATIVE ACTION: THE UNITED STATES \\ (version of Oct. 10, 2009)}

BY:

Professor Peter L. STRAusS

COLUMBIA LAW SCHOOL 


\section{Legal Frameworks and Institutional Contexts for Public Consultation Regarding Administrative Action: The United States}

\section{Peter L. Strauss ${ }^{1}$}

Introduction

The electronic democracy to which this volume is addressed finds reflection at all levels of American government, federal, state and local; and its tools could be employed by any political actor - legislature, political executive, or administrative bureaucracy. These pages will address practice only in the national government of the United States, and only in relation to essentially bureaucratic (administrative) actors. The American Congress, while maintaining a remarkable data base giving the public near simultaneous access to all records of its actions, ${ }^{2}$ has yet to develop regular electronic means for consultation with the public about its legislative agenda (contrasting sharply, in this respect, with the European Union, as addressed within.) Individual members may have web presences permitting consultations with their constituencies, but these are idiosyncratic and at an early stage of development. More is happening in presidential offices. The Director of President Obama’s Office of Management and Budget [OMB], within days of the President's inauguration, published a memorandum entitled "CitizenCentered E-Government: Developing the Action Plan,” promising that "Electronic government is one of the five key elements in the President's Management and Performance Plan.”3 An Office of E-Government \& Information Technology is an element of OMB, although at this writing its

1 Betts Professor of Law, Columbia University School of Law.

2 Thomas.loc.gov.

${ }^{3}$ http://www.whitehouse.gov/omb/memoranda_m01-28/. 
web-site is quite inactive. ${ }^{4}$, The Office of Science and Technology Policy [OSTP], ${ }^{5}$ a separate White House office, also addresses e-government issues; in May-July of 2009, under the leadership of Beth Simone Noveck, a noted American legal scholar of e-government, it conducted a web-based discussion of e-governance issues intended to inform the initiative, and, at this writing, its results can still be viewed on the Web. ${ }^{6}$ All this activity, however began too recently to be assessed in a paper principally written before President Obama’s election. Rather, these pages will focus on a context in which the use of electronic consultation by "executive branch” actors engaged in policy-making has been developing for over a decade, and has reached a point of considerable, although not final maturity. This is the American practice of developing administrative regulations (subsidiary legislation). Initially developed haphazardly, agency-by-agency, it is now (albeit with friction in the gears) moving towards a centralized regime. ${ }^{7}$ The practice is rarely consultative in the full sense suggested by the introduction to this collection of essays; as will appear within, while the public is given opportunities for input, and the input processes are transparent in varying degrees, online exchanges in the nature of a conversation or round-table are not imagined.

\footnotetext{
${ }^{4}$ http://www.whitehouse.gov/omb/e-gov/.

${ }^{5}$ http://www.ostp.gov/

${ }^{6}$ http://mixedink.com/opengov/, visited September 6, 2009. OSTP maintains an on-line blog, http://blog.ostp.gov/, where further developments on these and other e-government issues may be followed.
}

$7 \quad$ See the discussion in Part II, below. 
I. The organization of the federal executive for rulemaking in the United States

A. The general procedure

It seems useful first briefly to describe the procedures by which regulations (subsidiary legislation) are developed by the federal bureaucracy, without particular reference to the developing electronic components of the process. Rulemaking affirmatively requires statutory authorization, and occurs subject to more exacting judicial review for regularity than statutes receive, but it is strictly an executive branch activity. American law sharply distinguishes between rulemaking and legislation. Congress legislates, but it does not participate directly in rulemaking. It has the possibility of disapproving its result only by enacting a new statute. ${ }^{8}$

While exceptions exist, virtually any regulation purporting to govern private conduct must be adopted by procedures at least as rigorous as those described in Section 553 of the federal Administrative Procedure Act (APA). ${ }^{9} \quad$ Section 553 sets the ordinary procedures to be used by any agency statutorily authorized to adopt regulations. ${ }^{10}$ Other than a subsection enabling any person to petition an agency to undertake a rulemaking - a petition that must be responded to, and the denial of which is reviewable under quite permissive standards - it imagines rulemaking

8 The Congressional Review Act, 5 U.S.C. $§ 801$ et seq., creates a short form legislative process for such disapprovals, but as they must take the form of legislative action they require presidential agreement (or supermajorities in both houses to override a presidential veto). This makes likely, as thus far has proved to be the case, that such legislation will be successfully enacted only in very particular circumstances: when a with respect to regulation iss adopted in the waning days of one administration, but that remains open to the statutory process at the beginning of the next administration, in which both houses of Congress and the presidency are in the control of the other political party. Daniel Cohen \& Peter L. Strauss, Congressional Review of Agency Regulations, 49 ADMIN. L. REV. 95, 101 (1997).

$9 \quad 5$ U.SC. § 553.

10 Statutes governing the procedures required of individual agencies occasionally require more elaborate, socalled "hybrid" procedures - for example, requirements of oral elements - or may invoke a more formal procedure described in the APA itself for "on-the-record" rulemaking. As these do not significantly affect electronic usages, they will not be further discussed here. 
usually to begin with a notice of a proposal for rulemaking ${ }^{11}$ published in the daily Federal Register of government public notices. While the section itself is quite permissive respecting the necessary content of the notice, it is now understood that notice for any significant rule should contain the text of the proposed regulation and an explanation of its purpose, and that the agency should simultaneously make available the data or studies on which it may be relying in making the proposal.

As its second step, the section ordinarily requires the agency to give the public an opportunity to submit views and data -to comment on the proposal. The requirement is for an opportunity to submit written materials by a date certain, specified in the notice; agencies are free - but ordinarily not statutorily required - to introduce elements of orality into this comment process. $^{12}$ The APA imagines only one round of comments, so its text does not contemplate an opportunity to respond to the comments of others. With paper comments, perhaps simultaneously mailed to a single distant location, timely access to the comments of others was not expected and any access would be difficult. Agencies remained free, however, to consider late-filed comments and for important rulemakings there may occasionally have been efforts to reply to the timely posted and possibly significant submissions of others.

11 A little-used chapter of the statute, more recently enacted, provides for "negotiated rulemaking."- the development of the proposal in a public procedure, through the negotiations of a small committee of public and private persons selected for their interest in the matter., "negotiated rulemaking.” 5 U.S.C. §§ 561-70. While the processes for identifying the occasions for negotiated rulemaking and constituting its committee may involve electronic communication, in the manner of all government notices, negotiated rulemaking as such will not be further discussed here. See Philip J. Harter, Negotiating Regulations: A Cure for Malaise, 71 GEo.L.J. 1 (1982) and Philip J. Harter, Assessing the Assors: The Actual Performance of Negotiated Rulemaking, 9 N.Y.U. ENVTL. L. J. 32 (20001).

12 The exception would be for "hybrid" procedures requiring such an opportunity. Where "on the record" rulemaking is required, the APA gives the agency some discretion to use written procedures only. 
Section 553's third requirement is that the agency, after considering this commentary, publish a "concise general statement of . . . basis and purpose" as the preface of any regulation it finally adopts. Again, the language is modest, but courts have insisted upon relatively detailed explanations, including response to any adverse commentary that the reviewing court is persuaded to regard as having been "significant." Given the retrospective, litigation-driven character of this evaluation, statements of basis and purpose for important rulemakings have long and defensively exceeded the dimensions suggested by “concise general.” Adopted regulations, with their statements of basis and purpose, are also published in the Federal Register; the regulatory text, but not the statements of basis and purpose, are collected in the Code of Federal Regulations.

Agency "soft law" - guidance documents, interpretations, general statements of policy, staff manuals, and the like - is excepted from the procedures of Section 553. Section 552(a), however, part of the federal Freedom of Information Act, does anticipate that such documents can significantly affect private conduct and indeed are intended to be followed by agency staff. Thus, it twice provides, soft law documents may be used in a manner prejudicial to private interests only if published - either in the Federal Register or in an indexed compendium maintained by the agency.

\section{B. Presidential involvement in rulemaking}

If rulemaking is an executive branch activity, what is the role of the President? Recently, a majority of the Supreme Court sensibly treated an important rulemaking as executive action, and the constitutional challenge to it as being whether the authority conferred on an executive agency - the Environmental Protection Agency in this instance - was sufficiently bounded by 
statute to permit a court to assure its legality. ${ }^{13}$ Yet a majority of the Court has also said, in a proposition not called into question in any later opinion, that "the President's power to see that the laws are faithfully executed refutes the idea that he is to be a lawmaker." ${ }^{14}$ These two propositions, looking in quite opposite directions, are not easily reconciled.

The legislation authorizing rulemaking almost invariably makes it an agency activity, empowering a particular element of government, such as the Environmental Protection Agency or the Federal Communications Commission, to act within a limited frame of reference. These organizations are headed by persons appointed by the President, unmistakably Executive Branch officials; yet they are not the President. In recent decades, however, both the President and Congress have adopted measures creating significant roles for centralized oversight of rulemaking processes, roles that have tended to blur the lines between politics and administration.

On Congress's side, these include the National Environmental Policy Act, ${ }^{15}$ the Paperwork Reduction Act, ${ }^{16}$ the Regulatory Flexibility Act of $1980^{17}$ (subsequently amended and extended by the Small Business Regulatory Enforcement Fairness Act (SBREFA)), ${ }^{18}$ the Unfunded

13 Whitman v. Am.erican Trucking Ass’n, 531 U.S. 457, 471 (2001).

14 Youngstown Sheet \& Tube Co. v. Sawyer, 343 U.S. 579, 587 (1952).

$15 \quad 42$ U.S.C. $\S 4321$ et seq.

$16 \quad 44$ U.S.C. $\S 3501$ et seq.

$17 \quad 5$ U.S.C. $\S \S 601-612$.

$18 \quad 5$ U.S.C. §§ 801-808. 
Mandates Reform Act of 1995, ${ }^{19}$ the Electronic Freedom of Information Act of 1996, ${ }^{20}$ and EGovernment Act of 2002. ${ }^{21}$ The last two, which have significant implications for cyberdemocracy, are discussed below.

On the executive side, a considerable range of presidential documents also speak to agency procedures in rulemaking; of particular salience has been a series of Executive Orders, now described as Executive Order 12,866, providing for centralized review in the Office of Information and Regulatory Analysis [OIRA], another element of the OMB. ${ }^{22}$ While other White House offices, and the President and Vice President themselves, may significantly influence rulemaking from time to time, ${ }^{23}$ these are influences that tend to stay out of public view. Responding to concerns about OIRA's transparency and possibly inappropriate political influences on rulemaking's ostensibly open policy-making processes, President Obama quickly directed a thoroughgoing review of E.O. 12,866 and procedures under it - a review that voluntarily included a notice-and-comment process like that required of agency rulemaking, with

$19 \quad 2$ U.S.C. $\S \S 1531$ et seq.

20 Electronic Freedom of Information Act Amendments of 1996, Pub. L. No. 104-231, 110 Stat. 3048 (1996).

2144 U.S.C. $\S \S 3601$ et seq.

${ }^{22}$ http://www.whitehouse.gov/omb/inforeg_regmatters/

23 See, e.g., Elena Kagan, Presidential Administration, 114 HARV. L. REV. 2245 (2001) (recounting her experience of presidential direction of agency rulemaking during Clinton administration); Jo Becker \& Barton Gelman, Leaving No Tracks on Environmental Policy, WASH. POST, June 27, 2007, available at 2007 WLNR 12054552 (reporting that Vice President Cheney has attempted to control decisions as slight as the amount of water having to be released from a federal dam to protect threatened fish populations); Letter from Henry A Waxman, Chairman, H. Comm. on Oversight and Govt. Reform, to Susan A. Dudley, Administrator, Office of Info. and Regulatory Affairs (Apr. 30, 2008),at http://oversight.house.gov/documents/20080430103958.pdf. ("for over a year, the Office of Information and Regulatory Affairs has blocked the National Marine Fisheries Service from issuing a rule to protect [right] whales from being killed by ships. According to documents obtained by the Committee, the rule's delay appears to be due to baseless objections by White House officials.”). The rule was finally issued in midOctober 2008. 
a body of comments that at this writing remains posted on the web. ${ }^{24}$ Presumably changes will have occurred between this writing and its publication, and the OIRA website will help the reader find her way.

\section{IT resources for the stages of rulemaking}

As remarked above, the federal government’s IT presence began as an agency-by-agency process. Even government-wide resources, such as the Federal Register or the Code of Federal Regulations, were available on line and searchable only if and to the extent a responsible agency - in this case, the Government Printing Office - provided. For years, the best free internet source for the United States Code and the Code of Federal Regulations was a private site maintained by Cornell University, the Legal Information Institute;

Agency initiatives were highly variable. A few agency initiatives approached the concept of “consultation.” Thus, the Department of Transportation’s Research and Special Programs Administration (now its Pipeline and Hazardous Materials Safety Administration) has occasionally used chat rooms in connection with proposed rulemakings, incorporating the back and forth into its docket. At one point the Nuclear Regulatory Commission experimentally opened an interactive dialogue with members of its regulatory community on some technical issues of interest; the experiment, however, failed to generate significant participation. Once a Department of Agriculture rulemaking setting standards for organic produce had attracted a large and strongly committed audience, the Department provided an unusually full exposure of available data online, and invited more interactive commentary. What virtually all agencies ordinarily provided, however, was an opportunity to comment, and some access to materials

\footnotetext{
${ }^{24}$ http://www.reginfo.gov/public/jsp/EO/fedRegReview/publicComments.jsp
} 
already filed in electronic form.

Perhaps the most expansive early development of web-based resources for rulemaking occurred in the Department of Transportation, a cabinet department that, with its responsibilities for assuring the safety (inter alia) of all forms of transport, has become one of the government's major rulemakers. At an early stage in government's development of a web presence, it made a wide range of documents available and searchable on its website, accepted electronically filed comments, and developed "listserv" capacities permitting citizens to be informed of some filings of interest to them. Particularly significant was its development of a data management system (DMS) for all public documents held by the department, that was ultimately brought to the point of replacing the Department's paper records. Materials submitted or generated in paper form were promptly ${ }^{25}$ scanned into the docket, since that was the Department's only comprehensive record. This meant that all material that might be associated with a rulemaking docket could be found on the DMS, providing ready access from any computer to all associated scientific reports, or comments already filed. Thus, conceived as an efficiency measure for DOT employees, the DMS also greatly enlarged public access to the materials of rulemaking.

Today, all government rulemaking save that conducted by some "independent regulatory commissions" must be conducted through regulations,gov, a website presenting a uniform face for all, with materials presented (to the extent they are presented) via a single federal data management service (FDMS) that the public accesses through that site. Regrettably, it would take a major effort to produce the DMS's capacities in the FDMS, and thus FDMS is and appears likely to remain considerably more limited in content and usability. For example,

25 DOT's standard, generally met, was to post everything within eight working hours of receipt. The transition to FDMS, for which posting is more complicated, has slowed posting a bit. 
agencies are neither required, nor necessarily afforded the resources, to convert into electronic form materials that they receive in paper. Even for materials available to the agency in electronic form, the agency controls if and when they are posted to FDMS, and whether, if posted, they will be available to other agencies and to the public.. As a result, the FDMS cannot be regarded as a complete record of a rulemaking; nor is it a contemporaneous one

In 2008, anticipating the presidential election, the Administrative Law and Regulatory Practice Section of the American Bar Association published a report to Congress and the President on the status and future of Federal e-Rulemaking, "Achieving the Potential” (2008), that substantially informs this essay. ${ }^{26}$ Achieving the Potential provides a detailed account of the development of electronic rulemaking activities of the federal government, ${ }^{27}$ ultimately leading to regulations.gov and the FDMS - facilities still very much in the course of creation —and makes many recommendations for their improvement. The following paragraphs largely reorganize the ABA account, with reference as well to additional materials, to create a picture of the significance of Regulations.gov and the FDMS throughout the chronology of an ordinary rulemaking. As will become apparent, in addition to engaging the public, they also arm White House oversight and control over rulemaking.

A. The decision to undertake a rulemaking 1. Public petitions

Regulations.gov is structured to present rulemakings that have been proposed and to permit commentary on them. Hence, petitions to begin a rulemaking must still be filed in paper

${ }^{26}$ The Executive Summary of this report is attached as an Appendix. 
form, not electronically. Unless an agency chooses to invite comment on a petition for rulemaking, as of course it might, a petition is unlikely to become an element of the FDMS. ${ }^{28}$

2. The rulemaking plan/regulatory agenda

The brief discussion of rulemaking under the APA began with the agency's publication of a notice of proposed rulemaking, because (unless there has been a petition) that is where the statute first takes hold. Of course much occurs before this stage is reached. Bureaucratically there must be a decision to make a rulemaking effort - to begin analysis and drafting. For years now, both statute and Executive Orders (now, E.O. 12866) have addressed this decision.

Since 1980, the Regulatory Flexibility $\mathrm{Act}^{29}$ has required agencies to publish brief descriptions of these decisions, including contact information for interested persons, in regulatory agendas published each April and October in the Federal Register. Hard to search and incomplete, the agendas could be found electronically only on a site maintained by the University of Massachusetts. The regulatory agenda is an element of the FDMS, searchable via Regulations.gov, but agenda items are not directly linked to the relevant e-rulemaking docket, nor is the Agenda yet fully searchable. Regulations.gov provides no opportunity for a person finding a matter of interest on the regulatory agenda to enroll for notice of further developments; an RIN number that can be found in the agenda does provide a limited basis for integration of the regulatory agenda entry with the corresponding proposal for rulemaking, should one eventuate.

Since the mid-1980's, executive orders have required agencies to submit to the President

28 DOT, consistent with effective maintenance of complete electronic records on the FDMS, now that its DMS has been shut down, has created for itself a procedure within FDMS to permit electronic submissions, as of petitions for rulemaking, before a docket has been created. See docketsinfo.dot.gov.

${ }^{29}$ Note 17 above 
an annual "regulatory plan,” a requirement that for publication purposes is well integrated with the Regulatory Flexibility Act’s Unified Regulatory Agenda. Regulatory plans are obligations of every agency, including independent regulatory commissions, as well as the single-headed agencies like EPA and OSHA, albeit the enforcement of this obligation against the independent regulatory commissions is unclear. The regulatory plan and its processes are opaque to the internet. The current version of Executive Order 12,866 makes a variety of commitments to transparency respecting both its processes for overseeing individual rulemakings and the detailed impact analyses that it requires for the more important of these rulemakings. As developed below, this has resulted in web availability of a range of information. No such commitments are made in relation to the regulatory plan, and no electronic materials about it (beyond what may result from the inclusion of plan "events" in a regulatory agenda publication) are available on the web.

B. Development of a draft regulation

1. Required preliminary analyses

Under E.O. 12,866, agencies are responsible to submit to OIRA summary analyses of each projected individual rulemaking, which will include such matters as may be required by other measures, such as the Regulatory Flexibility Act. If the agency or OIRA concludes that the significance of the regulation under consideration requires extensive analysis under the terms of the order - a process that may involve informal consultations that will go unnoticed in electronic records - a formal draft analysis will be prepared and submitted.

Under the transparency commitments of the Executive Order, the fact of formal submission of a draft to OIRA, the pendency of its review, and a summary outcome are all noted and publicly available on the OIRA website. Should there be meetings at OIRA on the matter, 
the fact and subject of each meeting, together with a list of its attendees, will also be posted there. The draft itself, however, and any communications that may pass back and forth about it are not posted by OIRA. OIRA undertakes in the executive order both to limit the extent to which its consultations can be used by persons outside government for backdoor commentary, and to assure that written materials it sends to the agency will become a part of the agency docket, including an indication of changes made in the agency's formal submission during OIRA review. It is a matter of individual agency practice whether the content of meetings is memorialized in any way. While the draft analysis will be supplied to OIRA in electronic form, whether and within what time frame these records find their way onto the FDMS is agencydependent.

Since the Department of Transportation had committed itself to complete electronic dockets under its own docket management system before the decision to have a single FDMS was taken, DOT’s prompt posting of all materials is assured by the need for internal availability. That need puts into the rulemaking docket reasonably full accounts of meetings at OIRA, written materials coming from OIRA, and the like. The only question will be the fact and timing of their availability to the public - an issue that the FDMS system has thus far left to agency decision, and as to which the Department has thus far continued its practice of liberal exposure. The result is to bring these materials within the comment process.

Because the commitment to the FDMS is not a commitment to its use as a substitute for paper dockets, there is little certainty for agencies generally that materials like these will appear in it. That would require a commitment to translation hard copy documents into electronic form, entailing funds and personnel not readily available. Indeed, because an agency's decision to make materials it has placed on FDMS is binary - they may either be restricted to the agency 
alone or opened to outside access by both other agencies and the public - FDMS utility within government as well as without it, even as to materials that have been placed there, is significantly less than might be hoped for. Achieving the Potential reports that the "agency only” choice is often made, for reasons ranging from concern for pornographic content, to exposure of private business information, to compromising the internal deliberative process. These issues are compounded by significant limitations on searchability within FDMS, and its general inaccessibility to external search engines such as Google.

2. Data assembly and availability

What is true for OIRA's interventions is also true for the internal agency documents that may underlie eventual rulemaking. Scientific studies and other materials that courts may require be available for public comment, and that agencies would find themselves compelled to release in response to a generalized Freedom of Information Act request, need not be received in electronic form. If received in paper form, they need not be scanned into the FDMS, and thus will not be found there. This will include even draft economic impact statements made in compliance with E.O. 12,866, which requires them to be made available for public comment in association with a proposed rule. There is no requirement that the statement be made an element of the FDMS accessible to the public and other government agencies when the proposal itself is posted on Regulations.gov.

C. The notice of proposed rulemaking and opportunity to comment 1. Receiving notice

The formal place for publication of notices of proposed rulemaking remains the printed Federal Register. Nonetheless, agencies are obliged to make every notice of proposed rulemaking accessible through Regulations.gov, and to accept comments submitted by that 
portal. One might suppose Regulations.gov would offer some form of registration making it possible to receive notice electronically when matters of likely interest are posted or (as was possible on the DOT DMS system) whenever changes occur to a docket of known interest. At the moment, however, Regulations.gov affords strikingly limited possibilities for automatic notice. One may register only for an RSS feed for all notices appearing in the Federal Register. Once a docket number is known, one may register in connection with that - but docket numbers are known only after notice has been published. For any more pointed registration for rulemaking notices, one must rely on individual agencies - and the current approach to centralized e-government has disappointingly tended significantly to dampen agency initiatives in such matters.

\section{A one-way or two-way street? The chance to see and respond}

Consistent with the general current permissiveness of the FDMS system, while agencies are obliged to accept comments filed via Regulations.gov, they are not required to make that portal exclusive. Comments may be filed directly with the agency, either in paper or electronic form. Indeed, some limitations on the Regulations.gov interface (one can directly submit a comment of up to 2000 characters, and/or attach a single larger file) make it likely that direct submission of comments to the agency will continue to be the dominant form. Moreover, even if a comment is filed via Regulations.gov, it requires an affirmative decision by agency personnel for that comment to find its way into the publicly searchable areas of the FDMS. These decisions are inhibited by concerns about privacy and confidentiality, as already noted, and in any event need not be timely. Comments filed directly with the agency require additional steps if filed on paper, expensive and time-consuming ones. Achieving the Potential reports many reasons to believe that, at present, this process is slow when it happens, and incomplete. 
The conventional view of rulemaking - that it is a process by which agencies inform themselves -is not compromised by these lacunae. That there is a single deadline for the filing of all commentary entails the proposition that responsive comment is not an expected rulemaking element. Indeed, the governing Supreme Court interpretation of Section 553 emphatically rejects the idea that rulemaking entails a back-and-forth process, consultative in the fullest sense. ${ }^{30}$ Nonetheless, the remarkably expanded availability of materials promised by the information age carries with it the possibility of reading the comments of others much more readily than when doing so required a visit to a Washington office. In fact, many comments are filed before the stated deadline, permitting response. Most important, the "deadline” for commentary is highly artificial - it signals only that the agency's obligation to pay attention to what one might say ends. As would not be the case for a deadline in adjudication, it is not improper to submit a late-filed comment. Nothing prevents an agency from reading such a comment if it wishes to. It would not be surprising, in this respect, to see a gradual replacement of the "expert judgment" model currently underlying rulemaking by one that understood it in a more plebescitary, politically consultative light.

3. Decision processes within the administration Internally, the availability of rulemaking materials in electronic form can considerably aid decision processes. Important materials can be on as many desks simultaneously as need be. Software has been developed, Achieving the Potential notes, that permits amalgamating what may be a very large number of comments, and quickly distinguishing elements that are unique from those that may have been supplied to members by an interested NGO in the form of an

30 Vermont Yankee Vt. Yankee Nuclear Power Corp. v. Natural Res. Def. Council, 435 U.S. 519, 547-48 (1978).

Readers are entitled to know that the author, then General Counsel to the United States Nuclear Regulatory Commission, was an author of the government's brief in the case. 
electronic postcard - a considerable worksaving over manual processing. To the extent Regulations.gov becomes a portal used for such postcards - and they are more easily entered there than would be more detailed commentary - this may be an important benefit. "Grassroots" comment campaigns of this character of course predated it.

This is also the time when, for significant rulemaking, E.O. 12,866 requires submission and clearance of a final economic impact statement - a process thought often to entail a fair amount of pressure from the White House as to how contested elements should be resolved. ${ }^{31}$ Similar mechanisms and issues respecting transparency are present here as for draft statements at the pre-notice stage of the process.

\section{Adoption}

With adoption, regulations enter electronic databases associated with the Federal Register and the Code of Federal Regulations. Additionally, the Electronic Freedom of Information Act requires agencies to maintain an electronic library in which they can be found.

III. "Soft Law" - Guidance, the Web, and consultation

\section{A. E-FOIA}

With adoption of the Electronic Freedom of Information Act, federal agencies came under the legal obligation to make soft law instruments available in web-based "libraries,” a practice many agencies had already adopted voluntarily. This obligation has since been reinforced by OMB directives and advice. ${ }^{32}$ While not “consultation,” as such, these postings

31 Waxman Threatens to Cite Johnson With Contempt Over Documents, INSIDE THE EPA, June 20, 2008, 2008 WLNR 11540109 (reporting investigation into EPA Administrator Stephen Johnson's refusal to turn over documents related to the agency's ozone rulemaking, which President Bush appears to have directed to be amended hours before it was due for release).

32 See Memorandum from Office of Management and Budget to the Heads of Executive Departments and Agencies (Jan. 18, 2007), available at http://www.whitehouse.gov/omb/memoranda/fy2007/m07-07.pdf (including 
remarkably expand the transparency of government and, consequently, arm oversight, industry, and citizen petitions, and other responses pointing in a consultative direction. Particularly for science and technology-based regulators, such as the Federal Aviation Administration (FAA), the Nuclear Regulatory Commission (NRC), or the Food and Drug Administration (FDA), the volume of guidance materials issued by the agency may be an order of magnitude greater than its body of regulations.

The current preference for regulations that define results to be achieved ("standards") rather than specify the precise means to be employed ("rules") arms this phenomenon; once an agency has defined by regulation the results that must be shown, the regulated will enormously value advice from the agency about any (non-exclusive) means by which it has determined those results can be assured. But regulations generally, like statutes, invariably leave issues of detail and application unresolved, and one common kind of consultative practice is the advice letter, in which inquiring citizens or organizations are informed of an agency's interpretation of their legal obligations in relation to defined particular circumstances. This kind of soft law is hardly limited to technological regulation; the administration of tax, customs, and labor laws, among others, readily invite it.

The transformative effect of having this volume of materials available and readily searchable on the Internet can be easily appreciated. The author's favorite example, one of long standing, is the body of advice letters issued by the General Counsel of the National Highway Traffic Safety Administration of the Department of Transportation, in response to inquiries about the meaning and application of its regulations concerning motor vehicle safety. ${ }^{33}$ These letters

attachment “Final Bulletin for Agency Good Guidance Practices”)..

33 http://www.nhtsa.dot.gov/portal/site/nhtsa/menuitem.4d1e17245efafde89ec0f210dba046a0/ announces the 
have always been public documents, in the sense that any citizen could go to the office of the General Counsel and ask to inspect them. Previously, that would require searching physical files in Washington, D.C., perhaps imperfectly indexed and, in any event, likely a job for a hired agent - a lawyer, say - consuming expensive hours. For some years, the letters have been posted on the NHTSA website, and sitting at one's computer, it is possible in seconds to perform a search more accurate than the physical search could possibly have been. The value of this asset was so obvious that private organizations that had created their own electronic files of earlier letters donated their records to NHTSA as soon as this utility was created. Transparency and regularity were tremendously enhanced.

\section{B. Informal and encouraged practices}

The importance of guidance documents has resulted in increasing statutory and presidential attention to them. Congress has made FDA “Good Guidance Practices," initially an agency initiative to promote consultation with those likely to be influenced by its soft law pronouncements, into legally required procedures. ${ }^{34}$ (Since guidance, by definition, cannot be legally binding even if influential, this is itself a somewhat soft requirement. A search of Lexis on August 2, 2008 returned no federal cases (and 6 law review articles) referring to the FDA's guidance obligation.) In amendments adopted in 2007, President Bush added "significant” guidance documents to E.O. 12,866, requiring advance notification of them to OIRA, with the possibility that OIRA could require submission of a draft and brief explanation, and "notify the agency when additional consultation [with OIRA, that is] will be required before [its]

availability of the files and calls http://iseach.nhtdsa.gov.

34

Food and Drug Modernization Act of 1997, 21 U.S.C. §371(h). 
issuance.”35 Within a week, OMB had issued a "Final Bulletin for Agency Good Guidance Practices, ${ }^{36}$ itself the product of a public notice and comment process, requiring agencies to maintain a separate listing on its website of all guidance documents meeting the Executive Order definition, to "establish and clearly advertise on its Web site a means for the public to submit comments electronically ... and to submit a request electronically” for change, and to establish an office to receive and address complaints about guidance practices. ${ }^{37}$ The bulletin made clear that these requirements were not judicially enforceable, and that agency response to comments was not ordinarily required. ${ }^{38}$ However, for “economically significant guidance documents,” a subset of "significant guidance documents" defined as any that "may reasonably be anticipated to lead to an annual effect on the economy of $\$ 100$ million or more or adversely affect in a material way the economy or a sector of the economy" (excluding budgetary measures), ${ }^{39}$ the Bulletin instructed agencies to use procedures somewhat resembling notice and comment procedures, but apparently not requiring use of Regulations.gov for electronic consultation. ${ }^{40}$ It

35 E.O. 12,866, as amended by E.O. 13,422 (72 FR 2763, Jan 18 2007), Sec. 9.

36

Office of Mgmt. \& Budget, Final Bulletin for Agency Good GuidanCe Practices (2007), 72 Fed. Reg. 3,432, available at http://www.whitehouse.gov/omb/memoranda/fy2007/m07-07.pdf, 72 FR 3432 (Jan. 25, 2007). The authors of the document, Paul Noe and John Graham, have written discursively about it at Reflections on Executive Order 13,422: Due Process and Management for Guidance Documents: Good Governance Long Overdue, 25 YALE J. ON REG. 103 (2008).

37 Id. at, III.

$38 I d$. at, VI and III(2)(a).

39 Id. at, I(5).

40 In addition to publishing notice in the Federal Register that a draft document is available, the agency was to "Post the draft document on the Internet and make it publicly available in hard copy (or notify the public how they can review the guidance document if it is not in a format that permits such electronic posting with reasonable efforts)". Id. at., IV(1)(b). As of August 2, 2008, Regulations.gov lists no "economically significant guidance” for comment. 
appears that agencies are to use their own web-sites for receiving comments (if electronically

filed) and providing a responsive discussion of its conclusions once comments have been

received. Even though President Obama rescinded the amendment President Bush had made to Executive Order 12,866 extending its terms to guidance documents, this element was met with considerable approbation in regulated communities, and practices like these seem likely to continue.

Less formal, more immediate, and more intimate than the process for adopting regulations, it seems at least possible that these measures, for some agencies at least, will result in processes more genuinely consultative (in a public sense) than notice-and-comment rulemaking. The way in which Regulations.gov and the FDMS have been constructed limitations that will take much effort to overcome, quite possibly not forthcoming - tend to reinforce the pre-existing reality that “consultation” in rulemaking was often a better description of agency relations with the White House, than with the general public. Those consultations occur behind essentially closed doors that the Internet world does not seem poised to open. Over a decade and a half ago, an administrative law scholar who had served as general counsel to the EPA (one of the federal government's most important rulemakers and the managing partner thus far in the development of Regulations.gov and the FDMS) wrote:

What was once (perhaps) a means for securing public input into agency decisions has become today primarily a method for compiling a record for judicial review. No administrator in Washington turns to full-scale notice-and-comment rulemaking when she is genuinely interested in obtaining input from interested parties.

Notice-and-comment rulemaking is to public participation as Japanese Kabuki theater is to human passions - a highly stylized process for displaying in a formal way the essence of something which in real life takes place in other venues. To secure the genuine reality, rather than a formal show, of public participation, a variety of techniques is availablefrom informal meetings with trade associations and other constituency groups, to roundtables, to floating "trial balloons" in speeches or leaks to the trade press, to the 
more formal techniques of advisory committees and negotiated rulemaking. ${ }^{41}$

"Notice” of proposed rulemaking appears in Regulations.gov only after all these processes which are not on the web and likely not captured in any electronic record - have occurred, and the compromises resulting from them have been secured. To expect much movement often to occur at such a late stage in the development of a proposal is irrational. To attribute it to electronic processes that are not universal, and need not - probably will not - reflect even the totality of public inputs the agency has received, compounds the problem.

\section{Conclusion}

The foregoing paragraphs have attempted a descriptive, not a normative, account of the consultation situation respecting policy-making in the United States. One may see increasing commitments to transparency and interactivity as the Internet makes possible both the ready dispersion of knowledge, and broad opportunities for contribution. Whether, indeed, these developments will effectively enhance the experience and actuality of democracy in the affected communities is open to question. The model of Athens was unworkable even at the level of the eighteenth century nation-state, much less so large a community as the United States is today. Electronic communication opens avenues for participation, but hardly solves the problem of dealing with number, and may indeed complicate it - both in an ordinary way (e.g., the technology gap between rich and poor), and in vulnerability to manipulations. We may confidently expect these developments to continue, and significant problems to be revealed and require attention as they do.

41 E. Donald Elliott, Reinventing Rulemaking, 41 DuKE L.J. 1490, 1492-93 (1992). 